\title{
Plasmodium vivax and Mansonella ozzardi co-infection in north-western Argentina
}

\author{
María J Dantur Juri ${ }^{1}{ }^{2}$, Cecilia A Veggiani Aybar ${ }^{1}$, Eugenia S Ortega ${ }^{1}$, Guillermina B Galante \\ and Mario O Zaidenberg ${ }^{3}$
}

\begin{abstract}
A case of co-infection with Plasmodium vivax and Mansonella ozzardi was detected in a blood sample from a person who had shown symptoms of malaria and lived in a city that was close to the Argentina/Bolivia border. The case was detected during a random revision of thick and thin smears from patients diagnosed with malaria from various towns and cities located in north-western Argentina between 1983 and 2001. Trophozoites of $P$. vivax were observed in the thin blood smear along with M. ozzardi microfilaria (larval form), which presented a long, slender, pointed anucleate tail and the absence of the sheath. This last characteristic is shared with Mansonella perstans, Mansonella streptocerca and Onchocerca volvulus. More rigorously controlled studies to detect other co-infection cases in the area as well as the possibility of importation from Bolivia into Argentina are currently ongoing. The relationship between the malaria parasite and microfilaria, the potential effect of malaria treatment on the development of $M$. ozzardi, and the possible impact of this microfilaria on the immunity of a person against $P$. vivax are all still unknown. This contribution constitutes a point of focus for future studies involving the interaction between the parasites and the potential risk that humans are exposed to.
\end{abstract}

\section{Background}

Malaria caused by Plasmodium vivax spans the greatest geographic range [1]. Worldwide infections of $P$. vivax are estimated between 130 and 390 million, with 2.6 billion individuals living at risk of infection [1,2]. Severe and complicated malaria is generally caused by Plasmodium falciparum; however, an increasing number of $P$. vivax cases with severe manifestations have been reported recently $[1,3]$. It should also be noted that some researchers have cited cases of persons with malaria who do not present the typical symptoms caused by infection with P. vivax becoming asymptomatic patients [4-10].

The first cites of malarial disease in Argentina occurred between the end of the 19th Century and the beginning of the 20th Century and included reports on the geography of the disease within the country [11], the presence of both gametocytic and zygotic forms of Plasmodium

\footnotetext{
* Correspondence: juliadantur@yahoo.com.ar

'Instituto Superior de Entomología "Dr. Abraham Willink", Facultad de Ciencias Naturales e Instituto Miguel Lillo, Universidad Nacional de Tucumán, Miguel Lillo 205, (4000) San Miguel de Tucumán, Tucumán, Argentina ${ }^{2}$ IAMRA, Universidad Nacional de Chilecito, 9 de Julio 22, (5360) Chilecito, La Rioja, Argentina

Full list of author information is available at the end of the article
}

parasites in Anopheles mosquitoes [12], and the parasitological, epidemiological and entomological conditions of malaria in north-western Argentina, recognizing the presence of "tropic malaria" (produced by $P$. falciparum), a "tertian malaria" (produced by $P$. vivax) and a "quartan malaria" (produced by Plasmodium malariae), with all types co-existing at the same time [13].

Plasmodium vivax was the only malaria parasite reported in the north-west region of the country since the 1970s [14-19]. Positive testing of blood samples for $P$. vivax was due to active searches for sick people conducted by technicians of the Ministry of Health of Argentina.

Anopheles pseudopunctipennis is the main malaria vector in north-western Argentina [14-16]. Malaria caused by $P$. vivax and transmitted by $A$. pseudopunctipennis is much more benign compared to infections caused by other malarial parasites; commonly observed manifestations include intermediate episodes of fever and chills.

Nematodes that cause filariasis have been reported throughout the tropical regions of the world [20-22]. Generally, they are found accidentally when patients with symptoms of malaria visit the physician and thick

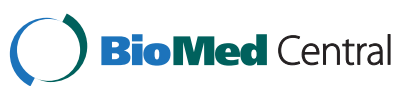


and thin blood smears reveal the presence of Plasmodium parasites with the larval forms of the nematodes called microfilaria. The presence of microfilaria infection in Argentina was recognized by malaria surveys in the northwestern region of the country [23], with the species Microfilaria tucumana first described [24] followed by Microfilaria dermaquayi [13,25], a homonym of Mansonella ozzardi [26], being described later. The high prevalence in the Tucumán, Salta, and Jujuy provinces in northwestern Argentina were reported by Mühlens et al. [13].

Mansonella ozzardi is endemic to the subtropical mountainous rainforest in the north-west region of Argentina [27]. In this region, transmission is related to ceratopogonid midges, Culicoides lahillei (main vector) and Culicoides paraensis (secondary vector) and black flies, Simulium exiguum (secondary vector) [28]. Although M. ozzardi is considered a relatively non-pathogenic filarial parasite, its pathogenicity is still a controversial subject requiring further study $[29,30]$. There is currently a lack of information about this disease, with the latest reports being those of Krolewiecki et al. [31] and Veggiani et al. (personal communication) on the influence of ivermectin in patients and the epidemiology of the disease in Argentina, respectively. A high prevalence of filariasis (20.7\%) was observed in one locality in the north-west region of the country [27]. A similar result has been observed (a prevalence of $26.0 \%$ ) in a rural community in the Bolivian Chaco region [32].

Plasmodium nematodes co-infection was widely reported in America [33-37]. Aráoz and Biglieri [23] and Rosenbusch [25] have cited numerous cases of people with microfilaria co-infection in the north-west region of Argentina. Later, Mühlens et al. [13] reported the finding of this microfilaria in blood smears with malaria parasites in the same region. Since this last paper, there were no reports of co-infections of Plasmodium microfilaria in the country; thus, the current study is the first report of the presence of $P$. vivax and $M$. ozzardi after several decades.

According to the World Health Organization (WHO) [19], Argentina is involved in the National Pre-Elimination Programme of Malaria with the aim to focus on the active detection of autochthonous cases. It has implemented several studies where the existence of co-infection of $P$. vivax with others parasites is considered important.

The present study aimed to detect co-infection with $P$. vivax and $M$. ozzardi in patients with a diagnosis of malaria who received anti-malaria treatment with primaquine-cloroquine in north-western Argentina from 1983 to 2001.

\section{Methods \\ Case description}

From October to December 2012, it was performed a preliminary analysis of 166 thick and thin smears from patient blood samples from different towns and cities situated in north-western Argentina, at the border with Bolivia, where there are still reports of imported malaria cases. These towns and cities included Aguas Blancas

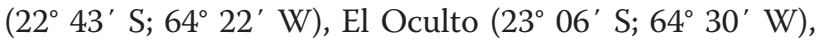

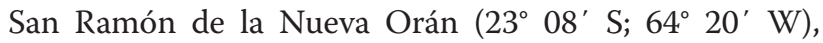

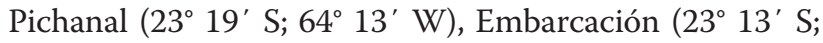

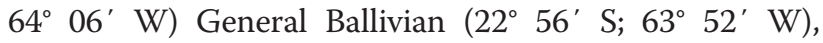
General Mosconi $\left(22^{\circ} 36^{\prime} \mathrm{S}\right.$; $\left.63^{\circ} 49^{\prime} \mathrm{W}\right)$ Tartagal $\left(22^{\circ}\right.$ $\left.32^{\prime} \mathrm{S} ; 63^{\circ} 49^{\prime} \mathrm{W}\right)$, Aguaray $\left(22^{\circ} 16^{\prime} \mathrm{S} ; 63^{\circ} 44^{\prime} \mathrm{W}\right)$, Campo Durán $\left(22^{\circ} 14^{\prime} \mathrm{S} ; 63^{\circ} 42^{\prime} \mathrm{W}\right)$ and Salvador

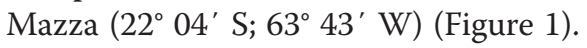

The reported case corresponds to a 70-year-old male living in the Tartagal locality, which belongs to the General José de San Martín Department, Salta province, north-west Argentina. The patient came to the regional malaria base with fever and chills. Microscopic revision was conducted on thick and thin smears, and parasites were visualized by using a binocular microscope with immersion lenses at $100 \%$ magnification. These tests revealed the presence of $P$. vivax - M. ozzardi parasites (Figure 2). The diagnosis was confirmed by a qualified specialist laboratory technician from the Reference Malaria Base of Salta City, Ministry of Health of Argentina.

The presence of $P$. vivax trophozoites was observed in the blood sample, showing an amoeboid cytoplasm and large chromatin dots. Mansonella ozzardi microfilaria appeared as described by Adami et al. [30] at the anterior region of the cephalic space that ends where the nuclear column begins, with an initial detailed nucleus followed by two that appear attached. The total length of the microfilaria was $148.2 \mu \mathrm{m}$ and their diameter was $3.1 \mu \mathrm{m}$; these values were included in the averages established for this species.

An epidemiological sheet was completed with the microscopic analysis of blood samples, including information related to the consultation date (day, month, year), the patient's name and address, place where the disease was supposedly acquired, travel during the previous three months, type of work, nationality and case classification. The epidemiological investigation revealed that the man living in Tartagal City and working in a banana farm close to the city acquired the malarial disease in Yacuiba (city on the Bolivia border) where he travelled two weeks before the report. The patient did not suffer any type of pain, with the presence of disease revealed by intermediate fever episodes. After laboratory confirmation, the treatment of the patient proceeded with a combination of chloroquine/primaquine pills for two consecutive weeks. The doses used were consistent with WHO guidelines [17] as follows: one tablet per day of chloroquine phosphate BP $242 \mathrm{mg}$ (Micro Labs Limited, Hosur, India) for two weeks and one tablet per day of Aralen phosphate/primaquine phosphate $15 \mathrm{mg}$ (Sanofi 


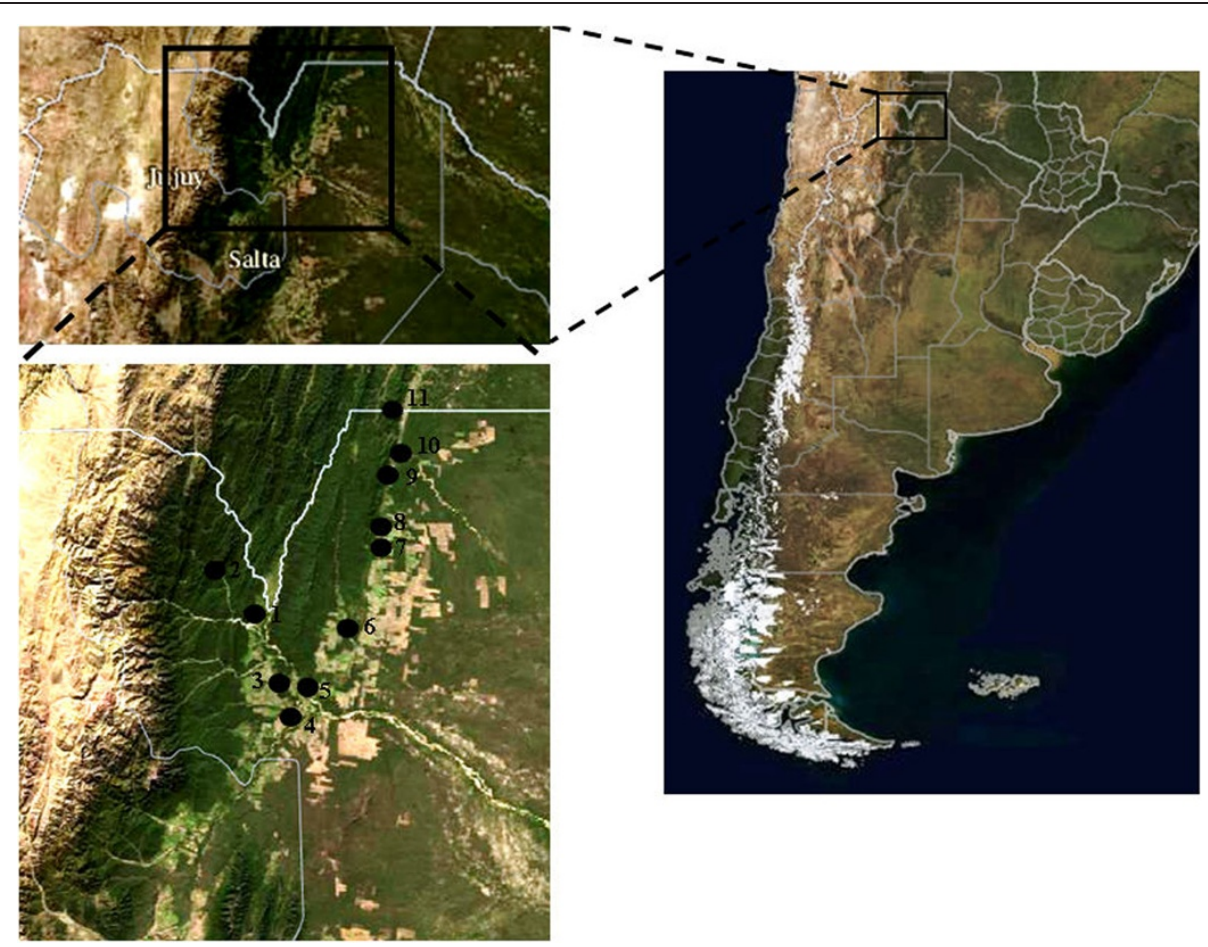

Figure 1 Geographical distribution of the localities in north-western Argentina (Aguas Blancas = 1, El Oculto = 2, San Ramón de la Nueva Orán = 3, Pichanal = 4, Embarcación = 5, General Ballivian = 7, General Mosconi = 8, Tartagal =9, Aguaray = 10, Campo Durán $=11$ and Salvador Mazza = 12).

Aventis U.S. LLC, Bridgewater, NJ, United States) during three consecutive days at the start of treatment. At this time, treatment for the filariasis parasite was not considered, and no complications were reported during or after the malaria treatment.

\section{Consent}

The study methodology, including the ethical aspects, was approved by the Ministry of Health of Argentina, which has an Ethical Committee who revised these aspects. They are included in the Protocol of the Manual

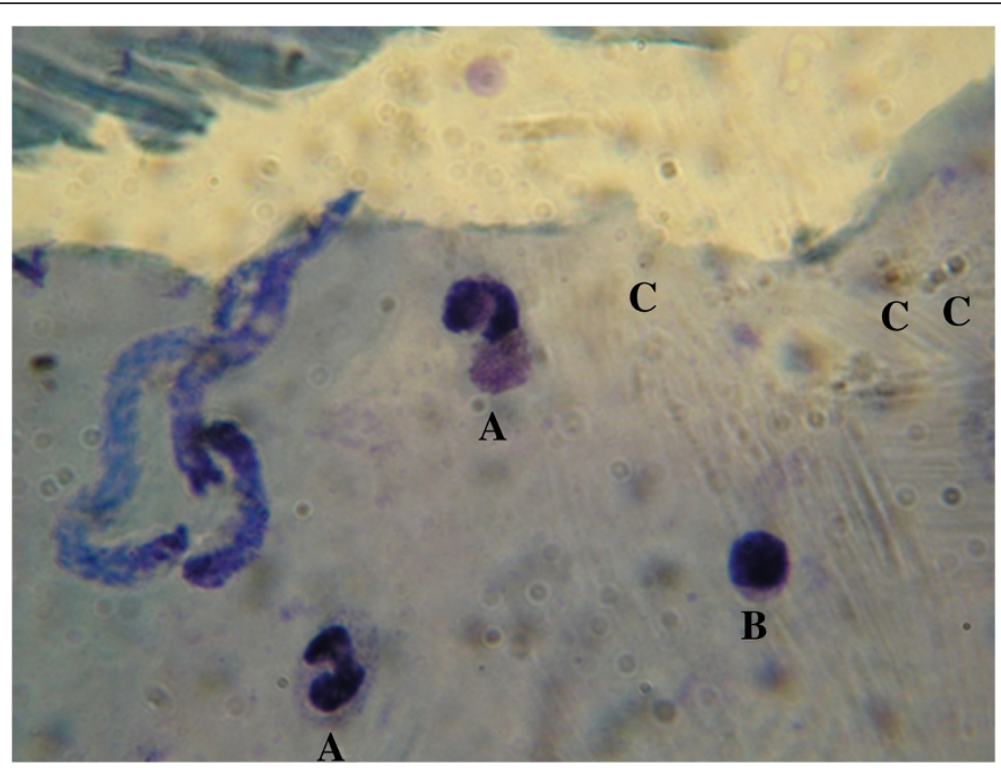

Figure 2 Microscopic analysis of Giemsa-stained thin blood-smears from a patient infected with Plasmodium vivax and Mansonella ozzardi microfilaria parasites ( $\mathrm{A}=$ neutrophils, $\mathrm{B}=$ lymphocyte and $\mathrm{C}=$ trophozoites). 
de Normas y Procedimientos de Vigilancia y Control de Enfermedades de Notificación Obligatoria, Ministerio de Salud Argentina.

\section{Discussion}

In north-western Argentina, the diagnosis of malaria is directly related to intermediate fever episodes, but the diagnosis of filariasis is a consequence of blood smear analysis for malaria. The first reports of malaria in Argentina showed that the disease was the most important parasitic disease of the time, not only because of the number of cases reported but also because of their wide geographical distribution across the country. The majority of malaria reports cited P. vivax as the most abundant parasite that appeared in blood smears, as well as the high prevalence of co-infection with M. ozzardi [26].

After the malaria eradication programme in 1959, malaria cases decreased considerably before a resurgence in disease in 1967 [38]. Since 1967, the active search for malaria patients by technicians of the Ministry of Health of Argentina, with adequate primaquine/chloroquine treatment, and the spraying in dwellings of the mosquito vector with $2.5 \%$ deltamethrin has reduced the incidence of malaria cases. The latest research indicates that the few autochthonous malaria cases were positive for $P$. vivax. This species seems to be the only parasite incriminated in malaria in human beings, and the most tolerant to the climatic and environmental changes, enabling its survival during this time in north-western Argentina [17-19,39]. The number of malaria cases with M. ozzardi co-infection also decreased dramatically during the last few decades, with the latest studies reporting high prevalence of microfilaria only within isolated communities, but affecting both sexes and with increasing infection rates progressively with increasing patient age [27,40-42].

\section{Conclusion}

From the present report, it has concluded that further studies are necessary to search for cases of co-infection with $P$. vivax and M. ozzardi. These studies should try to establish the prevalence of co-infection and quantify the potential effects of malaria treatment on the development of M. ozzardi and the impact of this microfilaria on the immunity of humans infected with $P$. vivax in north-western Argentina. The results presented in this study could be used as the basis for future studies involving the interaction of these parasites and include other localities on the Bolivian border, considering that the parasites and their vectors do not recognize geographical barriers to their transmission.

\section{Competing interests}

The authors declare that they have no competing interests.

\section{Authors' contributions}

MJDJ is a Research Assistant of CONICET and a Consultant of the Ministry of Health, this research is part of the studies that are ongoing in the country included in the Malaria Pre-elimination Phase according to the World Health Organization. She conceived the study and drafted the manuscript. CAVA checked all the human samples and also prepared the manuscript. ESO and GBG reviewed the literature and references. MOZ as a part of Ministry of Health of the Argentina contributed with the human samples to be analysed and participated in the edition of the manuscript. All authors read and approved the final manuscript.

\section{Acknowledgements}

We want to thank F Vianconi, N Vianconi, E Laci and J C Hitzamatzu (Coordinación Nacional de Control de Vectores (CNCV), Ministerio de Salud de Argentina) for carried out the collections of the hematic samples. We also thank laboratory technician N García (CNCV, Ministerio de Salud de Argentina) for her invaluable help in confirmation of parasite identification. This work was supported by Grants (PICT 01-04,347; PICT 02-12,605) from Agencia Nacional de Promoción Científica y Tecnológica (FONCyT), Consejo Nacional de Investigaciones Científicas Técnicas (CONICET), Consejo de Investigaciones de la Universidad Nacional de Tucumán (CIUNT), Coordinación Nacional de Control de Vectores (Ministerio de Salud de la Nación) and Fundación Roemmers of Argentina to MJDJ.

\section{Author details}

${ }^{1}$ Instituto Superior de Entomología "Dr. Abraham Willink", Facultad de Ciencias Naturales e Instituto Miguel Lillo, Universidad Nacional de Tucumán, Miguel Lillo 205, (4000) San Miguel de Tucumán, Tucumán, Argentina. ${ }^{2}$ IAMRA, Universidad Nacional de Chilecito, 9 de Julio 22, (5360) Chilecito, La Rioja, Argentina. ${ }^{3}$ Coordinación Nacional de Control de Vectores, Ministerio de Salud de la Nación, Güemes 125, Piso 1, (4400) Salta, Argentina.

Received: 10 May 2013 Accepted: 13 July 2013

Published: 17 July 2013

\section{References}

1. Kute VB, Goswami JG, Vanikar AV, Shah PR, Gumber MR, Patel HV, Kanodia KV, Trivedi HL: Unusual presentation of Plasmodium vivax: a neglected human malaria parasite. Parasitol Res 2012, 110:2573-2576.

2. Hay SI, Guerra CA, Tatem AJ, Noor AM, Snow RW: The global distribution and population at risk of malaria: past, present, and future. Lancet Infect Dis 2004, 4:327-336.

3. Lampah DA, Yeo TW, Hardianto SO, Tjitra E, Kenangalem E, Sugiarto P, Price RN, Anstey NM: Coma associated with microscopy-diagnosed Plasmodium vivax: a prospective study in Papua, Indonesia. PLoS Negl Trop Dis 2011, 5:e1032.

4. Jones SA, Ferreira Neto JA: Symptomless Plasmodium vivax parasitaemias and malaria eradication in Santa Catarina State, Brazil. Rev Soc Bras Med Trop 1971, 5:21-35.

5. Alves FP, Durlacher RR, Menezes MJ, Krieger H, Pereira Da Silva LH, Camargo AP: High prevalence of asymptomatic Plasmodium vivax and Plasmodium falciparum in native Amazonian populations. AmJTrop Med Hyg 2002, 66:641-648.

6. Vinetz J, Gilman R: Asymptomatic Plasmodium parasitemia and the ecology of malaria transmission. AmJTrop Med Hyg 2002, 66:639-640.

7. Coura JR, Suárez-Mutis M, Ladeia-Andrade S: A new challenge for malaria control in Brazil: asymptomatic Plasmodium infection - a review. Mem Inst Oswaldo Cruz 2006, 101:229-237.

8. Suárez-Mutis MC, Cuervo P, Leoratti FMS, Moraes-Avila SL, Ferreira AW, Fernandes $\mathrm{O}$, Rodrigues Coura J: Cross sectional study reveals a high percentage of asymptomatic Plasmodium vivax infection in the Amazon Rio Negro area, Brazil. Rev Inst Med Trop Sao Paulo 2007, 49:159-164.

9. Cucunubá ZM, Guerra AP, Rahirant SJ, Rivera JÁ, Cortés LJ, Nicholls RS: Asymptomatic Plasmodium spp. infection in Tierralta, Colombia. Mem Inst Oswaldo Cruz 2008, 103:668-673.

10. Cucunubá ZM, Guerra AP, Rivera JÁ, Nicholls RS: Comparison of asymptomatic Plasmodium spp. infection in two malaria-endemic Colombian locations. Trans R Soc Trop Med Hyg 2013, 107:129-136.

11. Cantón E: El paludismo y su geografía médica en la República Argentina. Buenos Aires: Imp. La Universidad; 1891. 
12. Delfino JC: Desarrollo y caracteres del paludismo en la ciudad de Santiago del Estero. Higiene: An Depto Nac; 1902:345.

13. Mühlens $P$, Dios $R$, Petrocchi $S$, Zuccarini J: Las filariosis argentinas: la microfilaria humana: estudio sobre el paludismo y hematologías en el norte argentino. Rev Inst Bact 1925, 4:336-342.

14. Bejarano JFR: Distribución en altura del género Anopheles y del paludismo en la República Argentina. Rev Sanidad Militar 1956, 55:7-24.

15. Curto SI, Carbajo AE, Boffi R: Aplicación de Sistemas de información geográfica en epidemiología: caso de estudio: malaria en la Argentina (1902-2000). GAEA, Sociedad Argentina de Estudios Geográficos 2003, 1-10:239-248.

16. Dantur Juri MJ, Zaidenberg M, Claps GL, Santana M, Almirón WR: Malaria transmission in two localities in north-western Argentina. Malar J 2009, $8: 18$.

17. World Health Organization: World malaria report 2010. Geneva, Switzerland: WHO Global Malaria Programme. WHO Library Cataloguing-in-Publication Data; 2010.

18. World Health Organization: World malaria report 2011. Geneva, Switzerland: WHO Global Malaria Programme. WHO Library Cataloguing-in-Publication Data; 2011.

19. World Health Organization: World malaria report 2012. Geneva, Switzerland: WHO Global Malaria Programme. WHO Library Cataloguing-in-Publication Data; 2012.

20. Buck AA, Anderson RI, MacRae AA, Fain A: Epidemiology of polyparasitism. I. Occurrence, frequency, and distribution of multiple infections in rural communities in Chad, Peru, Afghanistan, and Zaire. Tropenmed Parasitol 1978, 29:61-70.

21. Tshikuka JG, Scott ME, Gray-Donald K, Kalumba ON: Multiple infections with Plasmodium and helminths in communities of low and relatively high socio-economic status. Ann Trop Med Parasitol 1996, 90:277-293.

22. Chadee DD, Rawlins SC, Tiwari TSB: Concomitant malaria and filariasis infections in Georgetown, Guyana. Trop Med Int Health 2003, 8:140-143.

23. Aráoz J, Biglieri R: Casos de microfilaria observados por primera vez en Tucumán. An Dpto Nac Hig 1915, 22:151-159.

24. Padilla T: Filariasis latente de Tucumán. Semana Médica 1915, 22:371-383.

25. Rosenbüsch F: Algunas observaciones sobre las microfilarias encontradas en Tucumán. Inst Bact Dep Nac Hig 1915, 2:160-167.

26. Davis N: A study on the transmission of filarial Northerm Argentina. AmJTrop Med Hyg 1928, 8:457-466.

27. Taranto N, Castelli E: Detección de un foco de microfilariasis en el Noroeste Argentino. Rev Arg Microbio/ 1988, 20:49-51.

28. Shelley A, Coscaron S: Simuliid black flies (Diptera: Simuliidae) and Ceratopogonid midges (Diptera: Ceratopogonidae) as vectors of Mansonella ozzardi (Nematoda: Onchocercidae) in northern Argentina. Mem Inst Oswaldo Cruz 2001, 96:451-458.

29. Jörg M: Filaria por Mansonella ozzardi (Manson 1987), Faust 1929 en la Argentina con descripción de un caso grave. Prensa Med Argentina 1993, 70:181-190

30. Adami YL, Moraes MA, Lanfredi RM, Maia-Herzog M: An atypical microfilaria in blood samples from inhabitants of Brazilian Amazon. Parasitol Res 2008, 104:95-99.

31. Krolewiecki AJ, Cajal SP, Villalpando C, Gil JF: Ivermectin-related adverse clinical events in patients treated for Mansonella ozzardi infections. Rev Argent Microbiol 2011, 43:48-50.

32. Bartolini A, Cancrini G, Bartalesi F, Marcolin D, Roselli M, Arce CC Mansonella ozzardi infection in Bolivia: prevalence and clinical associations in the Chaco region. AmJTrop Med Hyg 1999, 61:930-933.

33. Biagi F, Tay J, De Biagi A: Observaciones sobre Mansonelosis en la península de Yucatán. Culicoides furens como transmisor. Rev Med México 1958, 38:377-379.

34. Lowrie R, Raccurt C: Mansonella ozzardi in Haiti Il: arthropod vector studies. AmJTrop Med Hyg 1981, 30:598-603.

35. Nathan MB, Tikasingh ES, Munroe P: Filariasis in Amerindians of Western Guyana with observations on transmission of Mansonella ozzardi by a Simulium species of the amazonicum group. Tropenmed Parasitol 1982, 33:219-222.

36. Peterson $J$, Bawden MP, Wignell FS, Latorre CR, Johnson CM, Miranda C: Mansonella ozzardi en el Darien (Panama). Rev Med Panama 1984, 9:236-246.

37. Arróspide N, Adami YL, Durand S, Rimarachín D, Gutiérrez S, Cabezas C: Microfilaria atípica en coinfección con Mansonella ozzardi y Plasmodium vivax en la Amazonía Peruana. Rev Peru Med Exp Salud Publica 2009, 26:408-416.

38. Carcavallo RU, Martínez A: Paludismo y sus transmisores: investigaciones científicas de las fuerzas armadas Argentinas. Com Cient Entomoepid República Argentina 1968, 13:145-186.

39. Ministerio de Salud de la Nación (Argentina): Boletín Epidemiológico (1997) Dirección Nacional de Epidemiología. Argentina: Departamento de Vigilancia Epidemiológica; 1997.

40. Remondegui C, Zaforoff G, Ripio C, Arce M, Neder De Roman L, Esquivel O: Mansonella ozzardi: Estudio Clínico Epidemiológico de un foco endémico en la Provincia de Jujuy. Acta Infectol 1988, 14:313.

41. Zaidenberg M: Filariasis en Balderrama, Provincia de Salta: aspecto epidemiológicos, año 1996. Medicina 1997, 55:23.

42. Zárate M: Filariasis en Balderrama. [Trabajo final del posgrado en Enfermedades Tropicales Transmisibles]. Salta: Universidad Nacional de Salta; 1996.

doi:10.1186/1475-2875-12-248

Cite this article as: Dantur Juri et al:: Plasmodium vivax and Mansonella ozzardi co-infection in north-western Argentina. Malaria Journal $201312: 248$

\section{Submit your next manuscript to BioMed Central and take full advantage of:}

- Convenient online submission

- Thorough peer review

- No space constraints or color figure charges

- Immediate publication on acceptance

- Inclusion in PubMed, CAS, Scopus and Google Scholar

- Research which is freely available for redistribution

Submit your manuscript at www.biomedcentral.com/submit
C) Biomed Central 